\title{
АКТУАЛЬНІ ПИТАННЯ БОРОТЬБИ 3 ТЕРОРИЗМОМ В УКРАЇНІ В СУЧАСНИХ УМОВАХ
}

\author{
Чередниченко О.Ю., к.е.н., доцент, докторант (УкрДУЗТ), \\ Чередниченко А.О., к.е.н., ст. викладач (ХНУМГ ім. О.М. Бекетова)
}

В статті обтрунтовано необхідність забезпечення життєво важливих інтересів людини, громадянина, суспільства $і$ держави в ході організації роботи з виявлення, запобігання і здійснення терористичних актів. Встановлено, щуо ключову роль в иььому прочесі відіграє не тільки СБ Украӥни, силові відомства, органи влади $і$ управління держави, а і громадянське суспільство. Констатовано про необхідність удосконалення правової бази щцодо боротьби з тероризмом.

Ключові слова: тероризм, терористичний акт, національна безпека, Антитерористичний центр при СБ України, СБ Украйни, екстремістські організації, загрози, антитерористична операція, терористична акція, правова база.

\section{АКТУАЛЬНЫЕ ВОПРОСЫ БОРЬБЫ С ТЕРРОРИЗМОМ В УКРАИНЕ В СОВРЕМЕННЫХ УСЛОВИЯХ}

Чередниченко А. Ю., к.э.н., доцент, докторант (УкрГУЖТ), Чередниченко А. А., к.э.н., ст. преподаватель (ХНУГХ им. А.Н. Бекетова)

В статье обоснована необходимость обеспечения жизненно важных интересов человека, гражданина, общества и государства в ходе организачии работь по выявлению, предупреждению и осуществления террористических актов. Установлено, что ключевую роль в этом прочессе играет не только СБ Украины, силовые ведомства, органы власти и управления государства, а и гражданское общество. Констатировано о необходимости совершенствования правовой базы по борьбе с терроризмом.

Ключевые слова: терроризм, террористический акт, национальная безопасность, Антитеррористический центр при СБ Украины, Службы безопасности Украины, экстремистские организации, угрозы, антитеррористическая операция, террористическая акция, правовая база.

\section{ACTUAL ISSUES OF COUNTER-TERRORISM IN MODERN CONDITIONS IN UKRAINE}

Cherednichenko O. U., Candidate of Economic Sciences, associate professor (USURT), Cherednychenko A. O., Candidate of Economic Sciences, p. teacher (O. M. Beketov National University of Urban Economy in Kharkiv)

The article substantiates the need to ensure the vital interests of man and citizen, society and the state in the organization of work to identify, prevent and terrorist acts. Found

(C) Чередниченко О.Ю., Чередниченко А.О.
Вісник економіки транспорту і промисловості № 57, 2017 
that a key role in this process is not only the Security Service of Ukraine, law enforcement agencies, authorities and government, but also civil society. Ascertained the need to improve the legal framework to combat terrorism.

Keywords: terrorism, act of terrorism, national security, Antiterrorist Center at the Security Service of Ukraine, the Security Service of Ukraine, the extremist organization, the threat against terrorism, terrorist action framework.

Постановка проблеми та її зв'язки з науковими та практичними завданнями.

Тероризм, який нажаль, стає невід'ємною частиною політичних і економічних процесів в світі та представляє собою все більшу загрозу громадській i національній безпеці, із поодиноких проявів перетворюється в масове явище. В сучасних умовах спостерігається ескалація терористичної діяльності не тільки екстремістських організацій, окремих осіб, а і цілих держав. При цьому ускладнюється характер їхніх дій, зростає нестандартність i жорстокість терористичних актів.

Причини терору криються в зростанні кризових явищ в економіці, нездатності суспільства регулювати складні соціально-політичні процеси, швидкій зміні систем людських i політичних ідеалів, цінностей, втягування до активного політичного життя широких мас населення 3 низькою духовністю, культурою та освітою, при цьому позбавленого політичного досвіду. Bce це активізує прагнення використати слабкості суспільної та державної системи, прокласти «найкоротший» шлях до поставленої мети.

$\begin{array}{cccc}\text { Аналіз } & \text { останніх } & \text { досліджсень } & \boldsymbol{i} \\ \text { публікацій. } & \text { Вагомий } & \text { внесок }\end{array}$
дослідження теоретично-методологічних засад та вивчення окремих аспектів протидії тероризму здійснили

такі українські та зарубіжні вчені, як В. Крутов, В. Антипенко, А. Дорошенко, В. Ліпкан, Л. Мошкова, I. Шкурат, Я. Дашкевич, В. Н. Кудрявцев, В.Тимошенко, С. Дрьомов, Бенджамін Дженкінс, Ернст Аречага, Раймон Арон, Юджин Дінстейн та інші. В той же час, аналіз динаміки здійснення терористичних актів як в Україні так і у світі свідчить про застосування терористами нових форм, засобів, висування нових вимог, обгрунтувань та виконавців, що свідчить про доцільність подальшого вивчення науковцями i практиками цих ганебних явищ 3 метою їх уникнення.

Метою статті $\mathbf{\epsilon}$ дослідження впливу такого явища сучасного суспільного i політичного життя як тероризм на стан забезпечення національної безпеки держави, вдосконалення алгоритму організації боротьби 3 тероризмом. Обгрунтування необхідності розширення правової бази боротьби з тероризмом в сучасних умовах розвитку держави, суспільства. Надання відповідних пропозицій щодо виправлення ситуації, що склалася в нашій державі.

\section{дослідження. \\ Виклад основного матеріалу}

Тероризм - суспільно небезпечна діяльність, яка полягає у свідомому, цілеспрямованому застосуванні насильства шляхом захоплення заручників, підпалів, убивств, тортур, залякування населення та органів влади або вчинення інших посягань на життя чи здоров'я ні в чому не винних людей або погрози вчинення злочинних дій 3 метою досягнення злочинних цілей [3].

Обов'язковими елементами, які характеризують тероризм $\epsilon$ : наявність насильства, як правило, збройного або його загрози; заподіяння чи загроза заподіяння шкоди здоров'ю людини, або матеріальних, моральних збитків; позбавлення або загроза позбавлення життя людей. Такі дії здатні викликати широкий резонанс, залишити глибокий 
слід у психології населення або значної його частини, підірвати атмосферу безпеки, спокою, стабільності в суспільстві.

Усі терористичні акції поєднані застосуванням насильства або погрозою насильства. Часто це супроводжується висуванням конкретних вимог 3 боку терористів, а насильство 3 їх боку спрямоване в основному проти цивільних об'єктів. Мотиви мають здебільш політичний характер. Акції відбуваються так, щоб привернути максимум суспільної уваги. Виконавці, як правило, члени організованих груп, на відміну від інших злочинців, беруть на себе відповідальність за вчинені акції. I, нарешті, сама акція покликана впливати, виходячи за межі заподіяння безпосередніх фізичних втрат.

Правову основу боротьби 3 тероризмом становлять Конституція України, Кримінальний кодекс України, закон України «Про боротьбу 3 тероризмом», інші закони України, Свропейська конвенція про боротьбу 3 тероризмом 1977p., Міжнародна конвенція про боротьбу з бомбовим тероризмом 1997p., Міжнародна конвенція про боротьбу 3 фінансуванням тероризму1999p., інші міжнародні договори України, згода на обов'язковість яких надана Верховною Радою України, укази Президента України, постанови та розпорядження Кабінету Міністрів України, а також інші нормативно-правові акти, що приймаються на виконання законів України.

Види i форми тероризму розрізняються за цілями, формами, методами, суб'єктами та об'єктами.

Сучасний тероризм розрізняють за такими різновидами:

- державний (організовується чи підтримується однією державою проти іншої);

міжнародними

- міжнародний

організаціями);
- внутрішньодержавний

(здійснюється замах на основи державності), релігійний (насаджується своє віросповідання);

- точковий (терористичний акт на окремо взятому об'єкті).

Беручи до уваги об'єкти замаху, тероризм можна умовно поділити на:

- елітарний ( при спробі замаху на посадових осіб органів державної влади, політиків, власників та керівників банків, компаній);

• функціональний (при спробі замаху на працівників правоохоронних органів, податкової служби, засобів масової інформації та ін.);

- промисловий (при нападі на великі підприємства, оборонні об'єкти, що виробляють зброю, отруйні чи інші хімічні речовини);

- транспортний (при використання вибухових пристроїв в літаках, поїздах, автобусах, автомобілях, диверсії на нафтота газопроводах).

Терористичний акт - злочинне діяння у формі застосування зброї, вчинення вибуху, підпалу чи інших дій, відповідальність за які передбачена статтею 258 Кримінального кодексу України[2].

Частина перша зазначеної статті розкриває зміст терористичного акта. Сюди входить застосування зброї, вчинення вибуху, підпалу чи інших дій, які створювали небезпеку для життя чи здоров'я людини або заподіяння значної майнової шкоди чи настання інших тяжких наслідків, якщо такі дії були вчинені 3 метою порушення громадської безпеки, залякування населення, провокації воєнного конфлікту, міжнародного ускладнення, або 3 метою впливу на прийняття рішень чи вчинення або невчинення дій органами державної влади чи органами місцевого самоврядування, службовими особами цих органів, об'єднаннями громадян, юридичними особами, або привернення уваги громадськості до певних 
політичних, релігійних чи інших поглядів винного (терориста), а також погроза вчинення зазначених дій 3 тією самою метою[2].

Кримінальна відповідальність також передбачена за втягнення у вчинення терористичного акту, публічні заклики до вчинення терористичного акту, створення терористичної групи чи терористичної організації, сприяння вчиненню терористичного акту та фінансування тероризму[2].

Боротьба 3 тероризмом діяльність щодо запобігання, виявлення, припинення, мінімізації наслідків терористичної діяльності.

Боротьба з тероризмом грунтується на таких принципах:

- законності та неухильного додержання прав і свобод людини i громадянина;

• комплексного використання з цією метою правових, політичних, соціальноекономічних, пропагандистських та інших можливостей; пріоритетності попереджувальних заходів;

- невідворотності покарання участь у терористичній діяльності;

- пріоритетності захисту життя i прав осіб, які наражаються на небезпеку внаслідок терористичної діяльності;

- поєднання гласних i негласних методів боротьби з тероризмом;

- нерозголошення відомостей про технічні прийоми i тактику проведення антитерористичних операцій, а також про склад їх учасників;

- єдиноначальності в керівництві силами i засобами, що залучаються для проведення антитерористичних операцій;

- співробітництва у сфері боротьби 3 тероризмом 3 іноземними державами, їх правоохоронними органами i спеціальними службами, а також 3 міжнародними організаціями, які здійснюють боротьбу з тероризмом[3].

Організація боротьби з тероризмом в Україні та забезпечення їі необхідними силами, засобами i ресурсами здійснюються Кабінетом Міністрів України у межах його компетенції. Центральні органи виконавчої влади беруть участь у боротьбі з тероризмом у межах своєї компетенції, визначеної законами та виданими на їх основі іншими нормативно-правовими актами.

Суб'єктами, які безпосередньо здійснюють боротьбу 3 тероризмом у межах своєї компетенції $є$ :

1) Служба безпеки України, яка є головним органом у загальнодержавній системі боротьби 3 терористичною діяльністю;

2) Міністерство внутрішніх справ України;

3) Міністерство оборони України;

4) центральні органи виконавчої влади (міністерства та відомства), що забезпечують формування та реалізують державну політику у сфері життєзабезпечення, транспорту та зв'язку;

5) центральний орган виконавчої влади, що реалізує державну політику у сфері захисту державного кордону;

6) центральний орган виконавчої влади, що реалізує державну політику у сфері виконання кримінальних покарань;

7) Управління державної охорони України[3].

Як правило для локалізації терористичної загрози проводиться антитерористична операція.

Антитерористична операція (АТО) - комплекс скоординованих спеціальних заходів, спрямованих на попередження, запобігання та припинення терористичної діяльності, звільнення заручників, забезпечення безпеки населення, знешкодження терористів, мінімізацію наслідків терористичної діяльності.

Рішення щодо проведення антитерористичної операції приймається залежно від ступеня суспільної небезпеки терористичного акту керівником Антитерористичного центру при Службі безпеки України за письмовим дозволом Голови Служби безпеки України 
або керівником координаційної групи відповідного регіонального органу Служби безпеки України за письмовим дозволом керівника Антитерористичного центру при Службі безпеки України, погодженим з Головою Служби безпеки України. Про рішення щодо проведення антитерористичної операції негайно інформується Президент України.

До участі в антитерористичних операціях за рішенням керівництва антитерористичної операції можуть бути залучені й інші центральні та місцеві органи виконавчої влади, органи місцевого самоврядування, підприємства, установи, організації незалежно від підпорядкованості і форми власності, їх посадові особи, а також громадяни за їх згодою.

Координацію діяльності суб'єктів, які залучаються до боротьби 3 тероризмом,

Антитерористичний центр при Службі безпеки України.

Антитерористична

операція

вважається завершеною, якщо терористичний акт припинено та ліквідовано загрозу життю і здоров'ю заручників та інших людей, які знаходилися в районі її проведення.

Рішення про припинення антитерористичної операції приймається керівником оперативного штабу 3 управління цією операцією. Сучасні події на Сході України де триває антитерористична операція дають привід переглянути підхід до визначення не тільки термінів проведення АТО, а й конкретніше визначити саме визначення антитерористичної операції, iї сутності.

Державні органи, органи місцевого самоврядування, об'єднання громадян, організації, їх посадові особи зобов'язані сприяти органам, які здійснюють боротьбу 3 тероризмом, повідомляти дані, що стали їм відомі, щодо терористичної діяльності або будьяких інших обставин, інформація про які може сприяти запобіганню, виявленню i припиненню терористичної діяльності, а також мінімізації іiі наслідків[3].

Практика проведення АТО на Сході нашої держави викрила певні проблемні питання, основні 3 яких виражаються у частковій втраті керованості та координації діяльності вищенаведених суб'єктів боротьби 3 тероризмом, a інколи i неможливості своєчасно та в повному обсязі виконувати поставлені завдання, що віднесені до їх компетенції. Ігноруванні традицій та особливостей розвитку окремих регіонів держави, норм національного та світового законодавства.

\section{Висновки.}

Тероризм у світі переслідується майже всіма державами. Підгрунтям для цього $\epsilon$ міжнародне законодавство, яке надає можливість переслідувати терористів на території будь-якої країни, а також національне законодавство, яке будується на нормах міжнародного права та враховує специфіку та традиції конкретних держав.

Антитерористична операція проводиться лише за наявності реальної загрози життю i безпеці громадян, інтересам суспільства або держави у разі, якщо усунення цієї загрози іншими способами є неможливим.

Аналіз останніх подій на сході нашої держави та безліч терактів в інших країнах світу, як в «гарячих точках» так і в стадіальних, благополучних країнах, способи та засоби їх здійснення дають підстави для перегляду не тільки механізму проведення АТО, а й пошуку нових форм її підготовки та проведення.

Нажаль після революції гідності разом 3 відміною ганебних, так званих пакетних «законів 16 січня», було скасовано дуже важливі законодавчі акти які внормовували поняття екстремізму, терористичної організації, механізм їх правового блокування та інше.

Тому, дуже гостро стає питання прийняття нових, більш сучасних та доопрацьованих аналогічних законів, що дозволить перевести дії щодо боротьби 3 
цими явищами в «правову площину». Розв'язання цих проблемних питань потребує комплексного системного підходу, участі в цьому процесі законодавчої та виконавчої гілок влади.

\section{ПЕРЕЧЕНЬ ИСПОЛЬЗОВАННЫХ ИСТОЧНИКОВ}

1. Європейська конвенція про боротьбу з тероризмом (ETS N 90) від 27 січня 19777 року № ETSN90

2. Кримінальний кодекс України від 5 квітня 2001 року № 2341-III № 100005 // Відомості Верховної Ради України. 2001. - № 25-26. - Ст. 131.

3. Закон України "Про боротьбу 3 тероризмом” від 20.03.2003 року №638IV// Відомості Верховної Ради України. 2003. - № 25. - Ст. 180.
4.Про основи національної безпеки України : Закон України від 19.06.2003 № 964-IV // Відомості Верховної Ради України (ВВР). - 2003. - № 39. - ст. 351.

5. «Про рішення Ради національної безпеки і оборони України від 2 вересня 2015 року «Про нову редакцію Воєнної доктрини України», Указ Президента України від 24.09.2015року №555/2015// Офіційний вісник України.-2015p. -№78. стаття 2592.-С.38.

6.Про Стратегію національної безпеки України: Указ Президента України від 26.05.2015 року № 287/2015 // Офіційний вісник України. -09.06.2015. №43. - стаття 1353. -С.38

7. Методичні рекомендації щодо підготовки населення до дій в умовах загрози або вчинення терористичного акту затверджені Наказом ДСНС України від 23.03.2015 року № 167. 